\title{
Communication and buildings. Space as mass-media
}

\author{
Anna P. Gawlikowska \\ Department of Mechanical Engineering, ETH Zurich, Switzerland, \\ e-mail:gawlikowska@lec.mavt.ethz.ch
}

\begin{abstract}
After providing definition and social roles of communication, media and mass-media, placing of architecture and urban space as one of the media types is proposed. Subsequently, architecture is looked at in the context of mass-media meaning transmission methods, roles, functions, effects and drawbacks. Articulating phenomena in architectural communication are listed, along with exemplary methods, in which design of space can shape public opinion. Models of mass communication are defined and discussed in context of architecture and urban space. This paper provides examples of short-, intermediate-, and long-term effects facilitated through space, as well as analyses, how architecture performs functions of media in society.
\end{abstract}

Keywords: Mass-media, architecture, urban design, communication, social rituals, symbols, language, transmission.

\section{Mass Communication}

Motto: "People tend to feel the similarities between the memory image and mental image, which means that if you look at them close enough, they will represent the same appearance, or the same organization." (Scruton [65])

Communication plays a large role in shaping modern culture, by selecting and portraying a particular set of beliefs, values, and traditions (an entire way of life), as reality. That is, by portraying a certain interpretation of reality, it shapes reality to be more in line with that interpretation (Vipond [2]). The term communication is derived from Latin communicare, meaning to impart, share, or make common (Peters [3]). Communication is a complex and interdisciplinary social process of exchange of meaning (Rittel [4]). The impact of message content changes in the course of contact between the means of communication and the audience (Goban-Klas [5]). Communication can be described as transmission of information, suggestions, ideas and emotions as an effect of interaction with symbols, images and signs. Symbols and signs transmit information through concept representations by a more essential and expressive means. They are customary, their meaning and understanding is often limited to a particular culture or social group. Therefore their communicative function is possible if both parties share a common semiotic code: system of symbols.

In the social context, communication can be described as means by which the group standards are expressed, social control is exercised, roles are assigned, coordination of efforts is achieved, and expectations are disclosed (De Fleur [6]). It allows socialization and organization, group identity creation as well as behavior and attitude shaping. Once communication is understood as all of the procedures by which 
one mind can affect another (Shannon \& Weaver [7]), all intentional methods, used by architecture to affect the users and observers can be qualified as communication. Therefore for the purpose of differentiation, social communication has been chosen as the focus of attention for the current paper. Symbols are regularly used in social communication, when groups, institutions, and advocates compete to identify problems, to move them onto the public agenda, and to define the issues symbolically (Finnegan and Viswanath [8]).

Mass media is defined as the channels of communication in modern societies that can reach large numbers of people, sometimes instantaneously (Sullivan [9]). Mass media play a significant role in shaping public perceptions on a variety of important issues (Lorimer \& Scannell [10]). Mass culture can be defined as a commercial culture, mass-produced for mass consumption by mass media (Storey [11], Campos Gonçalves [12]). In the context of this paper mass media will be understood in a broader way, with functions of social systems coordination, and inter-generational culture transmission (Lasswell [13]), information, interpretation, entertainment (Wright [14]) and social mobilization.

As a tool of social behavior, attitude and identity shaping, communication is used for politics and economy, and therefore is not free of issues of power and influence, impacting the transmitted message. Semiology describes social forms of communication (language, rituals, clothing, architecture, etc.). Dependencies on context and transmission intention, as well as complexity of cultural, social and political influences, make any single concept of mass communication inadequate. McQuail [15] provides qualification mass communication, recognizing four models: (1) transmission; (2) expressive/ritual; (3) publicity; (4) reception. The provided models differ in regards to orientation on the sender and receiver's part:

1. Transmission Model, where sender determines transmission of a fixed quantity of information, which is processed cognitively by the receiver. The model can be understood not fully linearly, but as shaped by receiver's feedback (Westley and McLean, [16]), as in the American free market model.

2. Ritual/Expressive Model perceives communication as ritual: communication is linked to such terms as sharing, participation, association, fellowship and the possession of a common faith (McQuail [17]). The relatively timeless message, basing on shared understandings and emotions, has a unifying effect, mobilizing sentiment, relations and action, therefore is often transmitted for the purpose of control and used by advertising and politicians. In this model, being decorative rather than utilitarian, sender provides performance, whereas receiver consumes and shares the experience.

3. Communication as display and attention: a publicity model does not aim to transmit particular information or to unite the public, by expression of cultural values, but is simply designed to gain attention. The sender provides competitive display, to catch and hold spectators attention, by means of arousing emotion and stimulating interest. In this model, the fact of attention matters more than the quality (Altheide and Snow [18]), and is perceived as consumption, which can be sold to advertisers.

4. Encoding and decoding media discourse: a reception model, where receiver constructs the meaning derived from media originates from critical theory, 
semiology and discourse analysis. In this model decoding is perceived as meaningful discourse, since message is polysemic - having multiple meanings depending on context and the receivers culture.

These models of communication will rarely occur in a pure form - and in social context both the generally understood communication, and the communication of space will be usually impacted by few of the listed transmission models.

Some of social communication is transmitted through media, which extend people's ability to communicate, to speak to others far away, to hear messages, and to see images that would be unavailable without media (Kreps and Thornton [19]). Among various media, mass media is particularly interesting, since it reaches large audiences, can be therefore compered with architectural objects in public spaces. Mass media definition recognizes the following media types: broadcast, print, outdoor (billboards, signs or placards placed inside and outside buildings, transportation means, as well as flying billboards) and digital (Internet, mobile communication). Within this definition, apart from traditional outdoor advertisement spaces, architecture and urban space is not considered as mass media, but according to the Author this description should be re-defined, involving them as types of outdoor mass media, not only as advertisement surfaces.

\section{Mass Communication through Space}

Psychologists and philosophers agree, that perception, experience and interpretation are inseparable. Architecture impacts perception and creates experience, has therefore a direct impact on interpretation and mental image creation (Scruton [20]). To communicate, architecture uses visual symbols and elements (rhythm, material properties, lines, shapes, colors, proportions, etc.), which provide an array of communicative elements, which can be abstracted and combined. They are, like language, able to articulate, along with other elements of architectural grammar (Durand [21]; Collins [22]; Eisenman [23]; Alexander et al. [24]; Ching [25]; Hill [26]). The articulating phenomena, mentioned by A. Forty (Forty [27]) include amongst others:

- Architecture formal characteristics: typology and style (Blondel [28] ; Norberg-Schulz [29]; Vidler [30]; Moneo [31]; Bandini [32]; Semper [33]); function, structure and organization (Viollet-le-Duc [34]; Frankl [35]; Sullivan [36]; Behne [37]; Taut [38]; Norberg-Schulz [39]; Collins [40]; Colquhoun [41]; Hillier [42]); form (Taut [43]; Alexander [44]; Venturi [45]; Eisenman [46]; Summers [47]);

- Architecture characteristics: character (Whatley [48]; Boffrand [49]; Viollet-le-Duc [50]; Norberg-Schulz [51]; Versely [52]); unity, truth and transparency (Wagner [53]; Gropius [54]; Baudrillard [55]; Tschumi [56]; Vesley [57]); poetry and rationality (Lethaby [58]; Vesley [59]);

- Context characteristics: spatial and historical context and continuity (Rossi [60]; Stern [61]; Rogers [62]); privacy and community (Alexander [63];).

Architectural and urban forms established as means of communication can be used in shaping public opinion, passing on the messages in accordance with their patrons vision. Due to the construction costs and needed regulatory power the building patrons often represent the minority elite. This fact is in alliance with classdominant theory of mass-media, stating that the media reflect the view of minor- 
ity elite controlling them (Mills [64]), and allow influence over society - country itself belongs to the person who controls communications (Eco [65]). The mentioned articulating phenomena can be used to shape the perception of audience inter alia through providing unifying cultural context - homogenizing agent (Littlejohn [66]). Architecture can be used as well as an element of symbolic domination over the territory and society. Symbolic domination is mastery over symbolic objects, things that are important symbols or signs for the social group. (...) This domination is a key symbolic element in political activity oriented at symbols. It is part of what is commonly referred to as the "political rituals" or "politics of symbols" (Nijakowski [67]).

Buildings are primary social objects (Markus [68]), not aesthetic or technical. In the context of mass communication models (McQuail [69]) architecture provides a complex array of meanings and plays various communicative roles.

Within the Transmission Model context, which is largely taken from older institutional contexts of education, religion and government, it provides the institutional, informational or propagandist solutions. The spatial examples of his model are multifold, and this is where the spatial design as mass media contributes to setting the hierarchy, and legitimizing power structures. It is also where symbolic objects are intentionally designed, using the grammar and communicative elements of architecture. The globally observed process of creating architectural objects built of more typical cognitive components, is linked with their potentially greater range of understanding by the world public, and therefore enlarged sales. The site effect of this process is the disappearance of works of revealing and unique character.

Within the Ritual/Expressive Model the architectural communication related to art, drama and entertainment can be categorized. Architecture, which is purely aesthetic and expressionistic, fits this category, along with public spaces, providing framework for social rituals and shared experience. Within this model symbolic communication ability of architecture, understood as mass-media can be qualified. Rituals in public space can be communicated in various manners through symbolic organization of space (Norberg-Schulz [70]), for example:

Center and road - in Christian world the road is designed towards the altar, symbolizing Christ - the goal of Christianity. Road - in the eastern religions the process is the goal by itself, and therefore shrines are designed basing on circulation around the common center (Fig. 1. Buddhist monument in Magelang, Indonesia). Center - the importance of symbolic center, which is space concentration and the specific organization, was present throughout most of the architectural styles. Closing of the place will have social implications - feeling of group togetherness, and focus on common goal. After a brief departure from the desire to symbolize, observed in the functionalist architecture, there was a return to the idea of center in pluralistic style (Fig. 2, Notre Dame chapel in Ronchamp).

Architecture, which provides advertisement and publicity fits into Publicity Model of mass communication, which is commonly associated with the role of mass media (Fig. 3. Exemplary architectural form, aiming at prestige and sales development, is the Apple Store in New York). Multiple architectural objects, like Eiffel Tower in Paris, are designed to gain public attention, to stimulate interest, and becoming touristic highlights, symbols of the city landscapes. The urban and architectural design is often conducted to gain and hold attention of the observer, by designed series of spatial stimuli. 


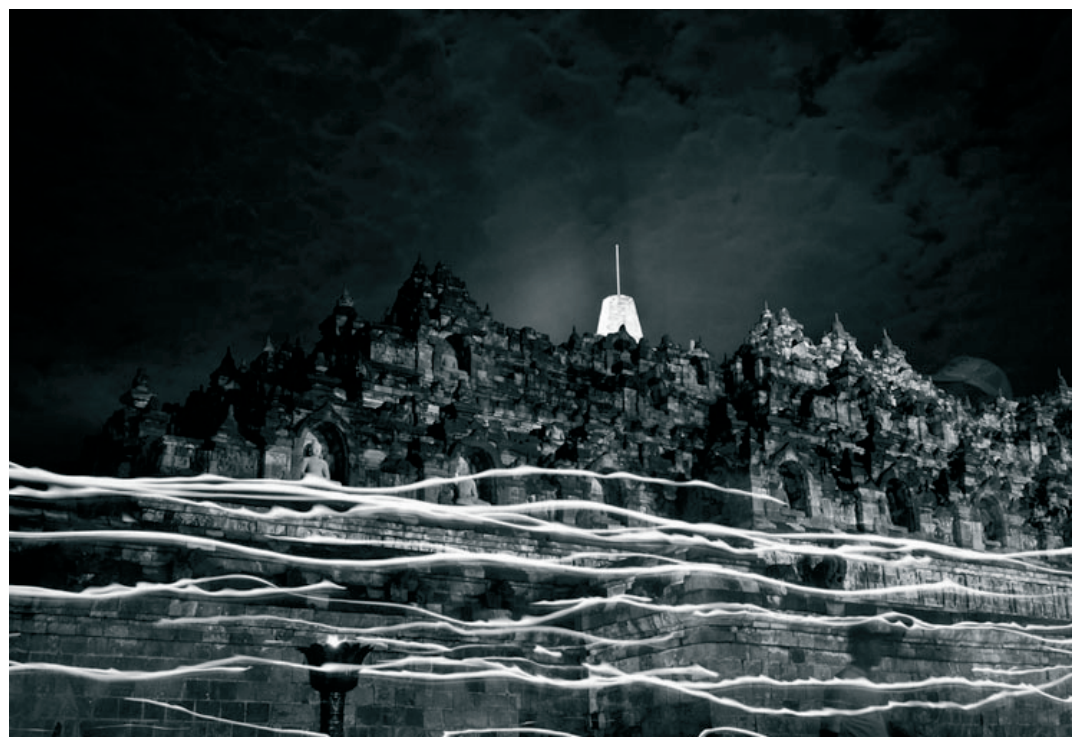

Fig. 1. Concept of center in the eastern religions illustrated by an example of Borobudur temple. Buddhists walk around the temple while carrying candles at the Borobudur Mahayana Buddhist monument in Magelang, Indonesia.

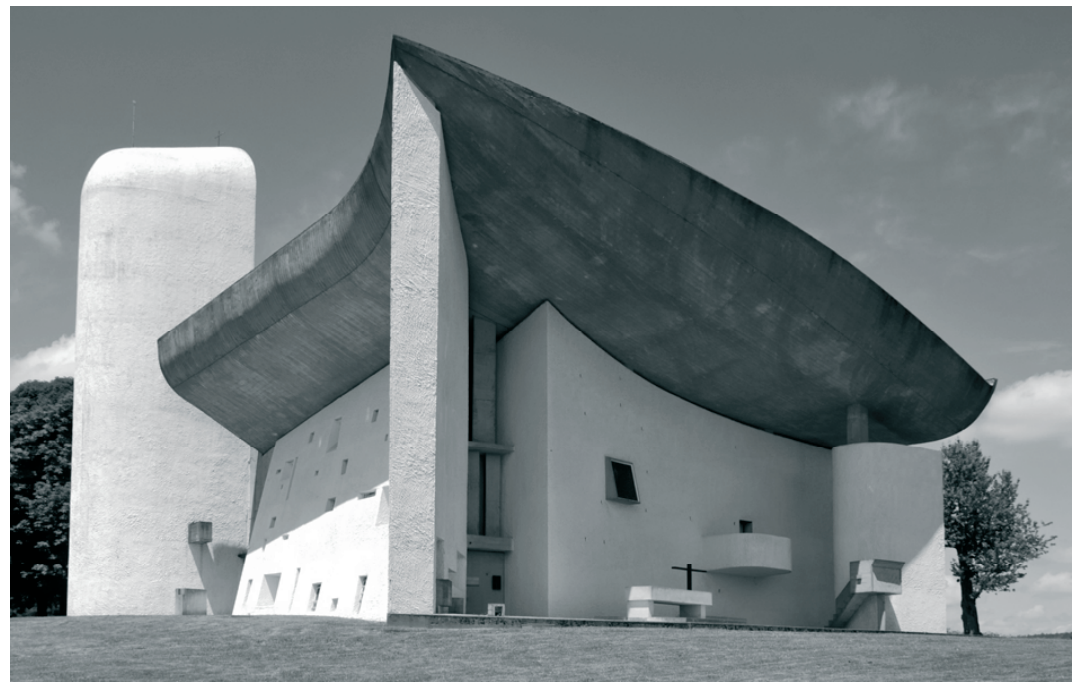

Fig. 2. Concept of center of meaning in the pluralistic architecture illustrated by Notre Dame du Haut in Ronchamp chapel by Le Corbusier's, 1953-1955.

Within the mass media context it should be mentioned, that urban landscapes are increasingly transformed into large advertisement spaces, with the most valuable areas around large mobility crossroads and symbolic dominants. The symbolic objects carry long lasting tradition of meaning and communal identity, are therefore attractive associations for the brands wanting to establish market presence. An illustration of this process is the occurrence, which took place in the early 90-ies, when the King Sigmund III Vasa column, located in front of the royal castle in Warsaw, has been dressed in St. Claus outfit, as a part of advertisement campaign. 
This violation of symbolic cultural structure has resulted in protests of the History Department of the Warsaw University (Kula [28]), leading to the campaign cancellation. Similarly planned McDonald's restaurant proposed location on the main square of Krakow has resulted in protests against the symbol of mass industrial civilization and superficial cosmopolitanism (...) to preserve cultural identity and historical character of this space (Kula [71]).

The Reception Model of mass media message transmission shows partially illusory power of architecture to mold, express and capture social attention, due to misunderstanding and misinterpretation of the encoded message by its receivers. The culturalist theory, developed in the 1980s and 90s claims that people interact with media (and architecture), and to create their own meanings and that audience members play an active, rather than passive role in relation to mass media.

Not all symbolic values of architecture are designed to be understood by it all users. There is a vast sphere of privacy, territoriality, and the related issues of human individualization. The Babel Tower can metaphorically illustrate this phenomenon, with its individualization problem resulting in lack of common language, identity and continuity (Fig. 4. Babel Tower Image). In the large metropolis of future, the various cultures live site-to-site, and often don't overlap, creating cultural and architectural ghettos. This lack of common language is further strengthened by communication being a dynamic, ever-changing, process, moreover the ingredients within a process interact; each affects all others (Miller [72]). In this context spatial communication is not a stable concept - it is subject to changes of built, technological, social, political and cultural environments, since the buildings are narrative, and their story consists of experiences, events and transformations until its destruction (Markus [73]).

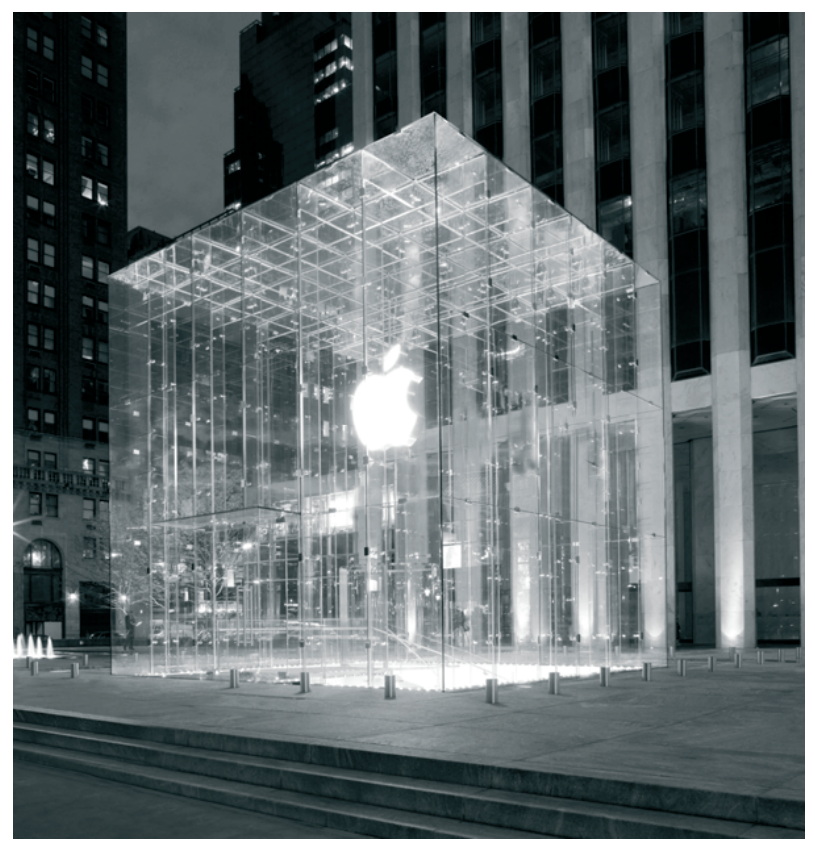

Fig. 3. Publicity architecture example: Apple Store, Fifth Avenue, NYC, opened in 2002, designed by Bohlin, Cywinski, Jackson company. 


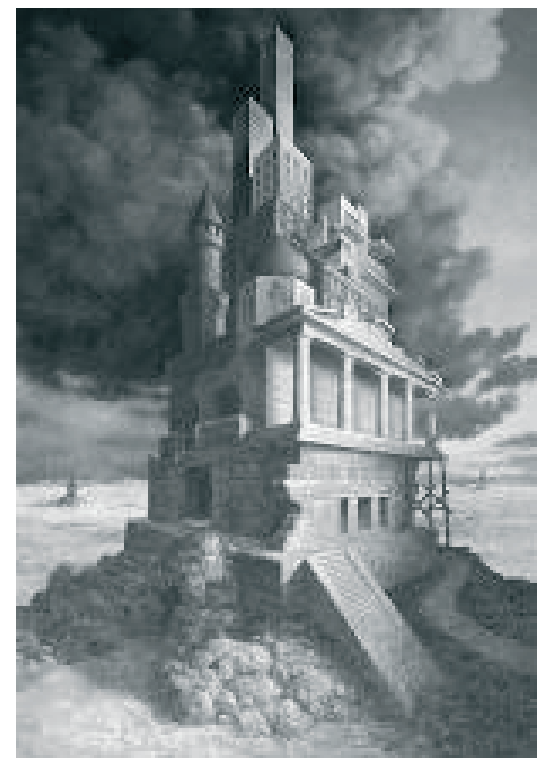

Fig. 4 . Painting of Babel Tower, Steven Kenny, 2000 - an interesting architectural interpretation of the semantic confusion.

As a part of mass media, architecture is capable of facilitating short-term, intermediate-term, and long-term effects on audiences. Short-term objectives include exposing audiences to concepts; creating intended awareness, knowledge and memory of advertisements. In this context architecture serves as an outdoor space for classical advertisement campaigns (billboards, LED screens, etc.), as well as for ambient advertisement (Fig. 5. Road safety Program advertisement and Fig. 6. Iberia advertisement), which uses space in an unusual manner, for example by projecting images on sites of buildings (Barnes [74]).

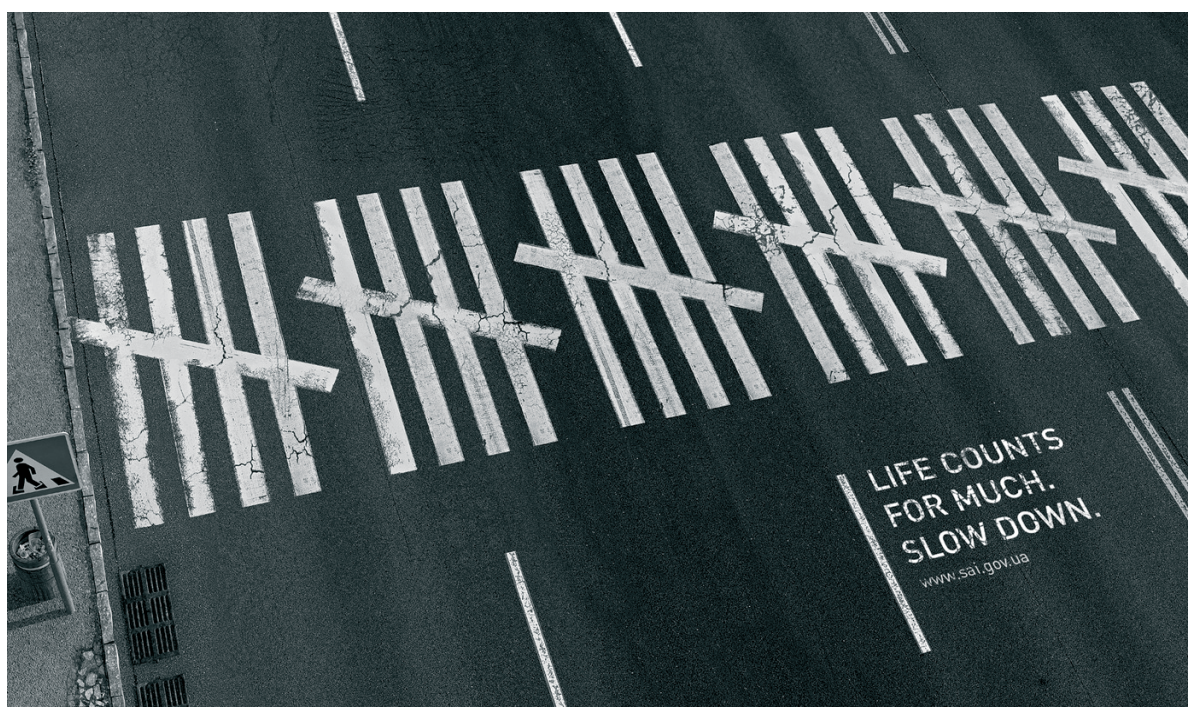

Fig. 5. Ambient advertisement using urban outdoor space, directed for both pedestrians and drivers. Advertisement created for the Road safety Program of State Auto Inspection. 


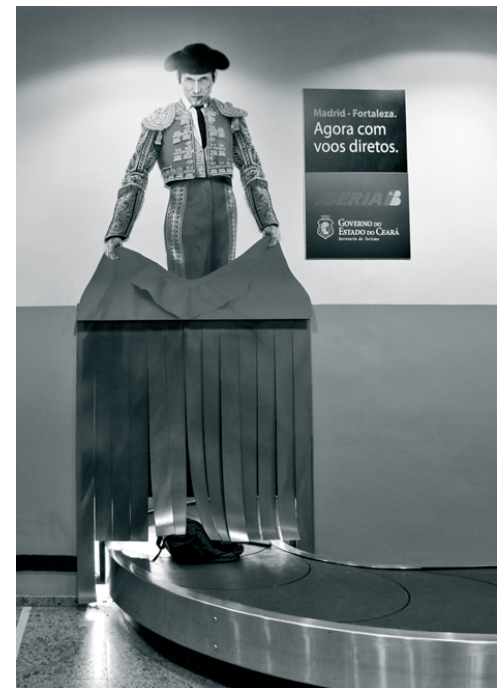

Fig. 6. Ambient advertisement using architectural interior, created for Iberia airline flights to Madrid. International airport, Pinto Martins.

Intermediate-term objectives of mass media, apart from the above characteristics, result in changes in attitudes, behaviors, and perceptions of social norms, whereas long-term objectives incorporate all of the above, as well as they restructure perceived social norms, and maintain behavioral change (Mcdermott and Albrecht [75]). Both the intermediate and long-term objectives of mass media can be directly met by architecture and urban space. This is possible due to the long-term presence of the built environment, its communication ability and influence upon social activities. This role of architecture is particularly important in context of contemporary society, characterized by pervasive change and the increasing speed - la societe des flux, which does not recognize permanent universal value hierarchy. For this reason the modern society needs stability, transmitted symbolically by significant stones (Schiller [76]). The existential meanings are derived from natural phenomena (...) and are felt as order and character. Architecture translates these meanings into spatial forms (Norberg-Schulz [77]), which can be considered significant to the society.

Architecture performs all tasks and functions of the media in the society listed by McQuail (McQuail [78]), including:

- Information - for example architectural objects can inform about their functions through the particular distinctive form (e.g. temple); they can also be used for indication of the balance of political power, since architecture can illustrate political hierarchy;

- Correlation - interpretation of the meaning of events is being performed for example by placing particular memorial spaces; socialization can be supported by appropriately design pro-social public areas; coordination of social action can be performed by spatial organization; creation of social and political consensus can be supported by symbolic social areas, authority and social status can be established through architectural symbols of power and control.

- Continuation - architecture can be used for expression of the dominant culture by adaptation of symbols and style related to the given culture, generation 
of community of values can be also supported by architecture, by creation of dominants in space related to specific value system, for example supermarket embodying commercial value-system.

- Entertainment - architecture can provide spaces for fun, rest and relaxation, for example sport areas, city parks, entertainment centers, thematic parks.

- Mobilization - public campaigns are often supported by spatial activities, for example public defilades on main squares (political and war campaigns), skyscrapers (economical development), areas conceived as sacral (religious purposes).

Among other key mass-media functions, architecture and public space assists organizations in achieving credibility and respect among public and gaining support. For example in context of hierarchical symbols is clearly visible: it illustrates the importance of symbolic values for the given social and political system through location and scale of buildings. Among other key mass-media functions, architecture and public space assists organizations in achieving credibility and respect among public and gaining support. For example in context of hierarchical symbols is clearly visible: it illustrates the importance of symbolic values for the given social and political system through location and scale of buildings embodying these values:

- Example of urban design, symbolically underlying value of intellect is Zurich, with the University of Zurich and the Zurich Technological University (ETH), located in the most prestigious point within the city structure;

- Bucharest with its massive structure constructed by Ceausescu (currently Palace of Parliament) symbolically illustrates the value of political power (Fig. 7 . Palace of Parliament);

- Limited scale and decoration of protestant city landscapes illustrate the importance of modesty within the social value system;

- Social equality was envisioned as an underlying value behind the social working class multifamily block unit (Fig. 8. City of Pyongyang);

- Value of community unity was the symbolic meaning behind the design of oval square in front of the St. Peter's cathedral in Rome.

The significance of architectural objects related to high values and universal archetypes occurs, because in accordance to psychological research the mobile world that is not based on the repetition of similarities associated with a stable system, would prevent the development of man and not permit also to the real interaction between people (Piaget [79]). In the context of current mass media development, architecture is essential to surpass momentary experience, providing symbols and anchoring memory (Fig. 9. Street in Toyko). At the same time media semantic code is increasingly becoming more global, connecting places, and reducing distance and time separation. Major trends in mass communication are said to have delocalizing effect, or to establish a new global "place", which increasingly people recognize as familiar (McQuail [80]), which gives architectural symbolic object a higher outreach then ever before. Destabilized society needs memory anchors, global society needs cognition anchors in form of symbolic images to map the complexity of the world. Since a well-developed media system, informing and teaching its citizens, helps democracy move toward its ideal state (McAllister [81]) well designed space can change society. 


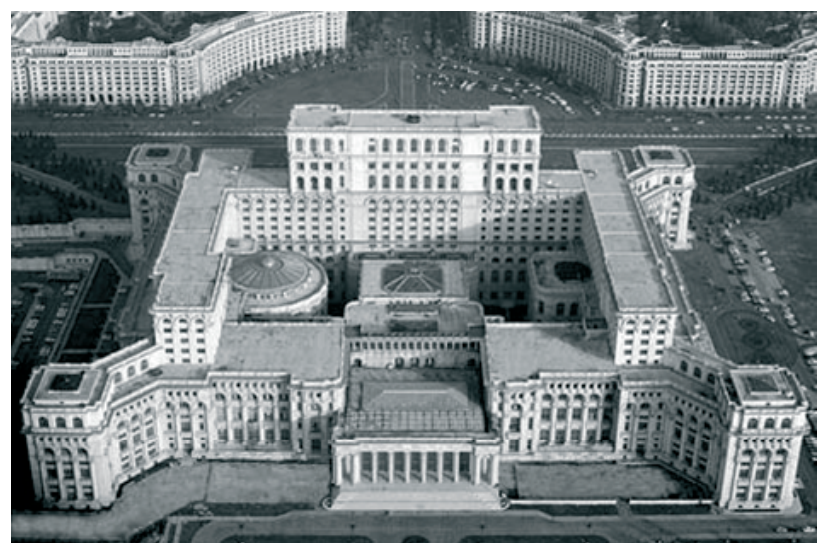

Fig. 7. Spatial symbol of political power constructed by N. Ceausescu: Palace of Parliament (originally People's House), 1984-1997, Bucharest, Romania. This neoclassical building is the world's largest and most expensive civilian building ${ }^{1}$.

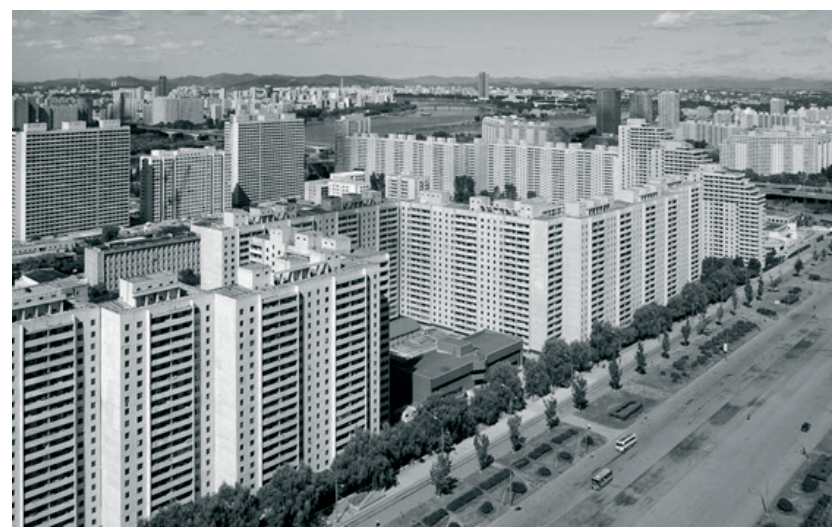

Fig. 8. North-Korean example of socialistic architecture: city of Pyongyang - a symbol of social equality of Northern Korean citizens.

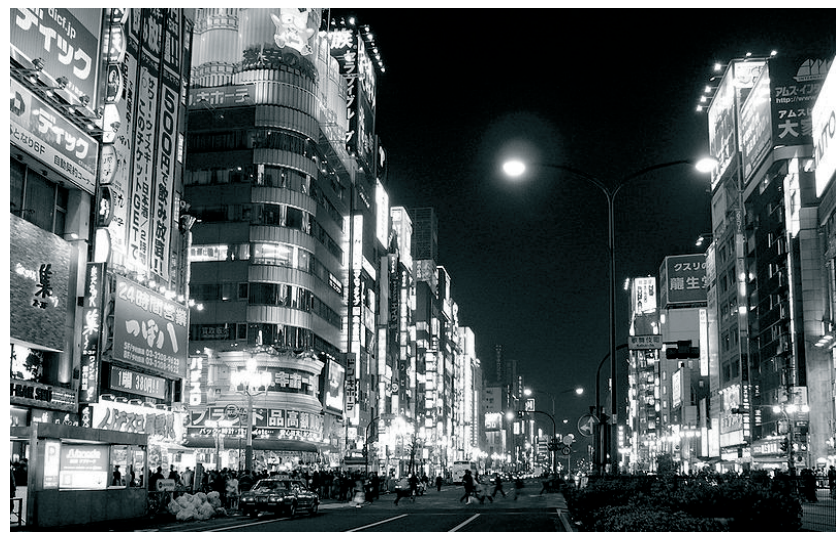

Fig. 9. Characteristic space of modern societies: speed, change and virtuality: Tokyo street at night.

1 According to World Records Academy. 


\section{Conclusions}

Architecture impacts perception and creates experience, therefore has a direct impact on interpretation and mental image creation. To communicate, architecture uses visual symbols and elements, which can be abstracted and combined. They are, like languages, able to articulate, along with other elements of architectural grammar, like typology, function, structure, form, character, context, etc.

Definition of mass-media, considering architecture and urban space as media only within the context of outdoor advertisement spaces, should be redefined involving them as types of mass-media, not only as advertisement surfaces. Architectural and urban forms understood as means of social communication can be used in shaping public opinion, passing on the messages in accordance with their patrons' vision. Architecture can be used to create control, standards, assign roles, coordinate, as well as transmit culture, information and interpretation. Architecture has an ability to perform key media functions, providing: information (e.g. indicating balance of political power); correlation (e.g. interpretation of meaning by particular memorials); continuation (e.g. symbolic community of values); entertainment (e.g. relaxation spaces); mobilization (e.g. space for public defilades supporting political processes).

In the context of mass communication models architecture provides a complex array of meanings and plays various communicative roles. Within the Transmission Model context it provides the institutional, informational or propagandist solutions. As a part of Ritual/Expressive Model it provides entertainment, and through symbolic space organization helps in constructing public rituals. Within the context of mass-communication Publicity Model it can serve both as publicity space as a means of advertisement through gaining public attention, stimulating interest, and symbolic objects transformation into city icons. Following mass-media Reception Model it should be noticed, that audience plays an active role in encoding the messages transmitted by spatial structures, resulting often in misinterpretation.

As a part of mass media, architecture is capable of facilitating short-term, intermediate-term, and long-term effects on audiences. This is possible due to the long-term presence of the built environment, its communication ability and influence upon social activities. In the context of current mass media development architecture is essential to surpass momentary experience, providing symbols and anchoring memory.

\section{Bibliography}

[1] Scruton R. The Aesthetics of Architecture. Methuen \& Co. Ltd, London, 1979.

[2] Vipond M. The mass media in Canada. James Lorimer \& Company, 2000.

[3] Peters J.D. Speaking into the air: A history of the idea of communication. Chicago, I L University of Chicago Press, 1999.

[4] Rittel S.J. Komunikacja polityczna. Dyskurs polityczny. Język w przestrzeni politycznej. Wydawnictwo Akademii Świętokrzyskiej, Kielce, 2003.

[5] Goban-Klas T. Media i komunikowanie masowe. Wyd. PWN, Warszawa, Kraków, 2002.

[6] De Fleur M.L. Theories of Mass Communication. D. McKay , New York, 1966.

[7] Shannon C.E., Weaver W. The Mathematical Theory of Communication. Urbana: The University of Illinois Press, 1949. 
[8] Finnegan J.R., Jr., Viswanath K. Communication Theory and Health Behavior Change: The Media Studies Framework. In: Health Behavior and Health Education, 2nd edition, eds. Glanz K., Lewis F.M., Rimer B.K. San Francisco: Jossey-Bass Publishers, 1997.

[9] Sullivan T. J. Sociology: Concepts and Applications in a Diverse World. Boston: Pearson Education, Inc, 2007.

[10] Lorimer R., Scannell P. Mass communications: a comparative introduction. Manchester University Press, 1994.

[11] Storey J. Cultural theory and popular culture. Pearson Education, 2006.

[12] Campos Gonçalves S. Cultura e Sociedade de Consumo: um olhar em retrospecto. InRevista - Núcleo de Produção Científica em Comunicação - UNAERP (Ribeirão Preto), vol. 3, 2008.

[13] Lasswell H.D. Power and Personality. W. Norton \& Company, New York, 1948.

[14] Wright C.R. Functional Analysis and Mass Communication. Public Opinion Quarterly, vol. 24, 1960.

[15] McQuail D. Mass Communication Theory. An Introduction. 5 Edition (2005), Sage, London, 1983.

[16] Westley B., McLean M. A conceptual model for mass communication research. Journalism Quterly, 34 (1957) 8-31.

[17] McQuail D. Mass Communication Theory. An Introduction. 5 Edition (2005), Sage, London, 1983.

[18] Altheide D.L., Snow R.P. Media logic. Beverly Hills, Ca, Sage, 1979.

[19] Kreps G.L., Thornton B.C. Health Communication Theory \& Practice. Prospect Heights, IL: Waveland Press, 1992.

[20] Scruton R. The Aesthetics of Architecture. Methuen \& Co. Ltd, London, 1979.

[21] Durand J.N.L. Précis des leçons d'Architecture données à l'École polytechnique. 2 vols (1819) 1802-1805.

[22] Collins P. Concrete. Faber and Faber, London, 1959.

[23] Eisenman P. From Object to Relationship II: Giuseppe Teragni Casa Giuliani Frigerio. Perspecta, vol. 13/14, 1971.

[24] Alexander C., Ishikawa S., Silverstein M. A Pattern Language: Towns, Buildings, Construction. Oxford University Press, New York, 1977.

[25] Ching F.D.K. Architecure Form, Space and Order. van Nostrand Rienhold, New York, 1979.

[26] Hill R. Designs and their Consequences. Yale University Press, New Haven and London, 1999.

[27] Forty A. Words and Buildings: a vocabulary of modern architecture. Thames and Huston, 2000.

[28] Blondel J.F. Cours d'architecture. 4 vols, Paris, 1771-77.

[29] Norberg-Schulz C. Intentions in Architecture. Scandinavian University Books, Oslo \& Allen and Unwin, London, 1963.

[30] Vidler A. The Third Typology. Oppositions, no. 7, 1977.

[31] Moneo R. On Typology. Oppositions, vol. 13, 1978.

[32] Bandini M. Typology as a Form of Convention. AA Files, vol. 6, 1984.

[33] Semper G. The Four Elements of Architecture and Other Wrightings. trans. Mallgrave H.F., Herrmann W., Cambridge University Press, 1989.

[34] Viollet-le-Duc E.E. $(1863,1872)$ Lectures on Architecture. trans. Bucknall B. (1877 and 
1881), Dover Publications, New York, 1987.

[35] Frankl P. Principles of Architectural History. trans. O'Gorman (1968), MIT Press, Cambridge, MA and London, 1914.

[36] Sullivan L.H. The Autobiography of an Idea. Dover Publications, New York, 1924.

[37] Behne A. The Modern Functional Building. 1926, trans. Robinson M., Getty Research Institute, Santa Monica, CA, 1996.

[38] Taut B. Die neue Baukunst in Europa und Amerika. Stuttgart, eng. trans: Modern Architecture, The Studio, London, 1929.

[39] Norberg-Schulz C. Intentions in Architecture. Scandinavian University Books, Oslo \& Allen and Unwin, London, 1963.

[40] Collins P. Changing Ideals in Modern Architecture 1750-1950. Faber and Faber, London, 1965.

[41] Colquhoun A. Plateau Beaubourg, in: Essays in Architectural Criticism. MIT Press, Cambridge, MA and London, 1981.

[42] Hillier B. Space is the Machine. Cambridge University Press, Cambridge, 1996.

[43] Taut B. Die neue Baukunst in Europa und Amerika. Stuttgart, eng. trans: Modern Architecture, The Studio, London, 1929.

[44] Alexander C. Notes on the Synthesis of Form. Harvard University Press, Cambridge, MA, 1964.

[45] Venturi R. Complexity and Contradiction in Architecture. Architectural Press, London, 1977.

[46] Eisenman P. From Object to Relationship II: Giuseppe Teragni Casa Giuliani Frigerio. Perspecta, vol. 13/14, 1971.

[47] Summers D. Form and Gender. in: Bryson, N. et al. (ed.) Visual Culture. Images and Interpretations. Hanover, New Hampshire, 1994.

[48] Whatley T. Observations on Modern Gardening. Dublin, in: Hunt and Willis, The Genius of the Place, 1770.

[49] Boffrand G. Livre d'architecture. Paris, 1745.

[50] Viollet-le-Duc E.E. $(1863,1872)$ Lectures on Architecture. trans. Bucknall B. (1877 and 1881), Dover Publications, New York, 1987.

[51] Norberg-Schulz C. The Phenomenon of Place. Architectural Association Quaterly, vol. 8, no. 4, 1976. In: Norberg-Schulz C. Genius Loci: Towards a Phenomenology of Architecture. London, Academy Editions, 1980.

[52] Vesley D. Architecture and the Poetics of Representation. Daidalos, no. 25, 1987.

[53] Wagner O. (1896) Modern Architecture. trans. Magllgrave, H. F. (1988), Getty Center, Santa Monica, CA.

[54] Gropius W. The New Architecture and the Bauhaus. Faber and Faber, London, 1935.

[55] Baudrillard J. Simulations. trans. Foss P., Patton P., Beitchman P., Semiotext(e), New York, 1983.

[56] Tschumi B. Disjunctions, in: Architecture and Disjunction. MIT Press, Cambridge, MA, and London, 1987.

[57] Vesley D. Architecture and the Poetics of Representation. Daidalos, no. 25, 1987.

[58] Lethaby W. R. The Architecture of Adventure. in: Form in Civilization, 1910.

[59] Vesley D. Architecture and the Poetics of Representation. Daidalos, no. 25, 1987.

[60] Rossi A. The architecture of the City. trans. Ghirardo D., Ockamn J., MIT Press, Cambridge, MA and London, 1966. 
[61] Stern R. At the Edge of Post-Modernism. Architectural Design, vol. 47, no. 4, 1977.

[62] Rogers E.N. Continuitá. Casabella continuitá, no. 199, 1954

[63] Alexander C. Notes on the Synthesis of Form. Harvard University Press, Cambridge, MA, 1964.

[64] Mills C.W. The Power Elite. Oxford Press, Oxfrord, 1956.

[65] Eco U. Towards a Semiological Guerrilla Warfare. first given as a lecture at conference Vision '67 in New York, 1967.

[66] Littlejohn S.W. Theories of human communication. 7th edition, Belmont, CA: Wadsworth, 2002.

[67] Nijakowski L.M. Domeny symboliczne. Konflikty narodowe i etniczne w wymiarze symbolicznym. Wydawnictwo Naukowe Scholar, Warszawa, 2006.

[68] Markus T.A. Buildings \& Power. Freedom \& Control in the origin of the Modern Building Types. London, Routledge, 1993.

[69] McQuail D. Mass Communication Theory. An Introduction. 5 Edition (2005), Sage, London, 1983.

[70] Norberg-Schulz Ch. Znaczenie $w$ architekturze Zachodu. Wydawnictwo Murator, Warszawa, 1991.

[71] Kula M. Nośniki pamięci historycznej. Warszawa, Wydawnictwo DiG, 2002.

[72] Miller G. A. Language and Communication. New York, McGraw-Hill, 1951.

[73] Markus T.A. Buildings \& Power. Freedom \& Control in the origin of the Modern Building Types. London, Routledge, 1993.

[74] Barnes J. Making a difference with ambient media. Admap, London, 1999.

[75] Mcdermott R.J., Albrecht T.L. Encyclopedia of Public Health. encyclopedia.com, 2002.

[76] Schiller F. Über die ästhetische Erziehung des Menschen. Epistle Publication, 1795.

[77] Norberg-Schulz Ch. Znaczenie $w$ architekturze Zachodu. Wydawnictwo Murator, Warszawa, 1991.

[78] McQuail D. Mass Communication Theory. An Introduction. 5 Edition (2005), Sage, London, 1983.

[79] Piaget J. The Psychology of Intelligence. Routlege and Kegan Paul, London / Littlefield, NY, 1968, in: Norberg-Schulz Ch. Bycie, przestrzeń i architektura. Wydawnictwo Murator, Biblioteka Architekta, Warszawa, 2000.

[80] McQuail D. Mass Communication Theory. An Introduction. 5 Edition (2005), Sage, London, 1983.

[81] McAllister M.P. The Commercialization of American Culture: New Advertising, Control and Democracy. Sage Publications, 1995. 